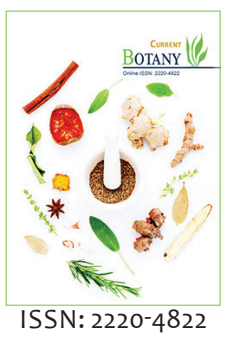

Received: February 23, 2021 Revised: March 21, 2021 Accepted: March 25, 2021 Published: April 15, 2021

*Corresponding Author: Qazi Parvaiz Hassan E-mail: qphassan@iiim.res.in

\section{Assessment of threatened status, phytochemical composition and biological properties of three Aconitum species from Kashmir Himalaya - India}

\author{
Sabeena Alia,b, Dilpreet Kour ${ }^{\mathrm{d}}$, Augustin Ntemafackc, Nitika Kapoorc, \\ Phalisteen Sultan ${ }^{\mathrm{b}}$, Ajay Kumar ${ }^{\mathrm{d}}$, Sumit G. Gandhi*a,c, Qazi Parvaiz Hassan*a,b
}

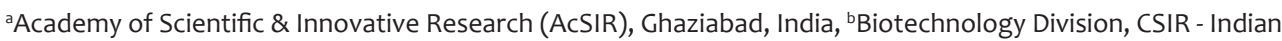
Institute of Integrative Medicine, Srinagar, 190005, J\&K, India, 'Plant Biotechnology Division, CSIR - Indian Institute of Integrative Medicine, Canal Road, Jammu, 180001, J\&K, India, dPKPD Toxicology \& Formulation Division, CSIR - Indian Institute of Integrative Medicine, Canal-Road, Jammu-180001, India

\begin{abstract}
Genus Aconitum (Ranunculaceae) is represented by 6-8 species from Kashmir Himalaya. Traditionally Aconitum species are used to treat a wide array of diseases, but their ethnopharmacological validation and phytochemistry are hitherto unreported from Kashmir Himalaya. The present study was undertaken to bring insights into the traditional use and distribution pattern of three Aconitum species from the region. An ethnobotany-directed approach was employed to study the conservation status of three Aconitum species. Their phytochemical profiles and biological properties were screened under in vitro conditions. Folin-ciocalteu and Aluminium chloride assays were employed to measure their total phenolic and total flavonoid contents, respectively. Plant extracts were evaluated for antioxidant, antimicrobial and anti-inflammatory activities. Three Aconitum species, viz. Aconitum heterophyllum Wall. ex Royle, Aconitum violaceum Jacquem. ex Stapf and Aconitum chasmanthum Stapf. ex Holmes showed dwindling conservation status in Kashmir Himalaya. Aconitum extracts showed significant variations in total phenolic and flavonoid contents. Antioxidant activity of Aconitum chasmanthum methanolic extract was studied to be comparatively higher (80.115\%). Aconitum chasmanthum DCM \& methanolic extracts showed a good MIC value of $0.125 \mathrm{mg} / \mathrm{ml}$ against Candida albicans and Streptococus pyogenes, respectively. The percent inhibition of NLRP inflammasome was found significant in Aconitum violaceum ethyl acetate extract $(74.61 \%)$. The present study revealed that Aconitum species are constantly declining at least in investigated habitats of Kashmir Himalaya and hence need strategic conservation planning. The results also emphasized the utility of Aconitum species as antioxidant, antimicrobial and anti-inflammatory agents that could be used to manage various health problems.
\end{abstract}

KEYWORDS: Aconitum; Kashmir Himalaya; Conservation status; Antioxidant activity; Antimicrobial activity; Antiinflammatory activity

\section{INTRODUCTION}

Genus Aconitum (Ranunculaceae) is represented by approximately 300 species worldwide (Utelli et al., 2000). About 166 species of Aconitum have been reported from Southwest China and Eastern Himalaya (Liangqian \& Kadota, 2001) and 11 species from Pakistan (Qureshi \& Chaudhri, 1988). In India, the genus is represented by 27 species distributed in alpine and sub-alpine zones of Himalaya extending from Kashmir to Uttarakhand and to the hills of Assam (Balakrishnan et al., 1993). Previously, 6-8 species have been reported from Kashmir Himalaya (Conventry, 1930; Jabeen et al., 2013). Aconitum is one of the most precious natural sources of highly useful bioactive metabolites such as aconitine, mesaconitine and hypaconitine possessing significant antitumor and immunostimulant properties. They are used to cure nervous system disorders, rheumatism, diabetes (Chhetree et al., 2010; Yang et al., 2017) and are effective against multi-drug resistant cancers (Wada et al., 2015). Traditionally, the leaves of Aconitum species are used to treat common ailments like cough, cold, fever, diarrhoea and vomiting (Shah, 2005). The rhizomes of Aconitum species are used in combinatorial form with other medicinal herbs for curing kidney and bone-joint discomforts, dyspepsia, bronchitis and skin diseases. Traditionally, Aconitum has been used as

Copyright: (C) The authors. This article is open access and licensed under the terms of the Creative Commons Attribution License (http://creativecommons.org/licenses/by/4.0/) which permits unrestricted, use, distribution and reproduction in any medium, or format for any purpose, even commercially provided the work is properly cited. Attribution — You must give appropriate credit, provide a link to the license, and indicate if changes were made. 
an integral medicine in treating nervousness, oral infection, heartburn, abdominal pain and also consumed to control blood glucose levels and taken as tonic by malaria patients to increase body vigour (Dar \& Naqshi, 2001). Earlier it has been reported that decoction of Aconitum species was used to treat urinary tract infections (Lone et al., 2012) and abdominal disorders (Khan et al., 2004). Aconitum has been used as febrifuge to treat throat infections, dyspepsia and diabetes (Tantray et al., 2009). Since Aconitum has been used in different systems of medicine for curing various diseases; as such the increasing demand of Aconitum species has led to overharvesting of its tubers resulting in rapid depletion of its natural stocks. In the last few decades, the genus Aconitum has been exploited and the consequence is that many of its species have been listed as endangered in the Red Data Book (Dar \& Naqshi, 2001). The findings regarding the distributional data of Aconitum species from North Western (NW) Himalaya is well recorded. Aconitum violaceum is considered as vulnerable, whereas Aconitum heterophyllum as critically endangered (Rana \& Samant, 2010). As per IUCN Red List Categories and Criteria (2010), Aconitum heterophyllum is reported as endangered however, Kaul had assigned it as vulnerable in Kashmir Himalaya (Kaul, 1997). Over the years, the species density of Aconitum has substantially decreased while its commercial demand has increased. Additionally, adequate measures have not been taken yet to multiply and domesticate its species. In the present study, we attempted to characterize the conservation status of three Aconitum species in Kashmir Himalayan region. The occurrence of Aconitum species was carried out by monitoring the field data at different altitudinal zones. Also taken into consideration the vast number of ethanopharmacological properties, the present study was attempted to carry out antioxidant, antimicrobial and antiinflammatory properties of these Aconitum species.

\section{MATERIAL AND METHODS}

\section{Search Strategy}

\section{Identification of Localities}

The findings concerning the studies associated with distribution and ethnopharmacological evidence of three Aconitum species was carried out by searching different electronic databases, viz. Scifinder, Science Direct, Research Gate, Google Scholar, BioOne, and PLOS. The published literature was reviewed to gather the information about the biodiversity of Aconitum species of Kashmir Himalaya. The information on occurrence data of Aconitum was collected from two herbariums [University of Kashmir \& CSIR-IIIM, J\&K, India], which made it easy to approach to the regions of interest. The locations were visited with special emphasis from vegetative phase to the harvesting period of the desired plants. To avoid erroneous identification, focused group consultations with many respondents having sound knowledge of Aconitum, discussions with occasional practitioners for verifying the plant samples were executed. The data collected was also re-examined from natives of different regions by providing different vernacular names of plant specimens. Specimen photographs were shown to the natives to notify the ethnopharmacological claims of Aconitum species.

\section{Herbarium Data Retrospection}

The herbarium, viz. KASH Herbarium, University of Kashmir and Janaki Ammal Herbarium, CSIR-IIIM, J\&K-India, were approached to collect the information of distribution patterns of all the available specimens deposited at respective places.

\section{Collection and Sampling Method}

The sampling of the plants was done by 'random approach' involving the collection of three Aconitum species found in the study area and 'ethnobotany-directed' sampling approach, based on traditional medicinal uses of Aconitum species.

\section{Study Site Description}

In the present study, the area comprises the accessible alpine and sub-alpine regions of the Kashmir Himalaya. Different locations were selected (Figure 1) and surveyed for the collection of different species of Aconitum according to the documented herbarium reports.

\section{Distribution Pattern of Aconitum}

The taxonomic relevance and distribution pattern of three Aconitum species was taken into account by surveying the selected belts frequently and contemplating the relevant literature and herbarium sheets at KASH Herbarium [Centre for Biodiversity and Taxonomy], University of Kashmir, Srinagar, J\&K. The occurrence of different species of Aconitum was recorded by various aspects, viz. population density within 1 $\mathrm{km}^{2}$ area, herbivory score, vulnerability score (0-3) and area of occupancy. The vulnerability assessment for Aconitum species in the region was followed by a standardized procedure (Wild \& Mutebi, 1996; Uniyal et al., 2011; Lone et al., 2018).

\section{Ethnobotanical Findings}

The data acquisition based on ethnobotanical knowledge was compiled for documentation in the vegetative seasonal period of the three Aconitum species by following a standard prototype. To record the complete information of Aconitum, questionnaire was followed comprising the information about plant local names, vegetation season, medicinal uses, mode of consumption, dosages and diseases cured (Pardo-de-Santayana et al., 2007). The information about the traditional medicinal knowledge of Aconitum species particularly from the tribal community of Gujjar \& Bakkarwals was reported in order to make the findings more reliable. During the study period, the ethnomedicinally important sites, viz. Yarikhah, Gulmarg, Kangdoori, Apharwat, Khilanmarg, Hapatkhod, Dodpathri, Aharbal, Kausarnag, Dachigam, Naranag, Gurez, Kokernag, Ahlan, Verinag, Pahalgam, Aru, Sonmarg, Thajwas, Drass and Panikhar of different altitudinal ranges were chosen (Figure 1). The selected ranges were inspected routinely during harvesting 
period of Aconitum species with special emphasis to collect different accessions. To avoid erroneous identification, focus group conversation with key respondents and herbal specialists (Hakeems) having good traditional knowledge of medicinal plants (Pardo-de-Santayana et al., 2007) was executed to verify the plant samples and their ethnopharmacological claims.

\section{Preliminary Phytochemical Screening}

\section{Preparation of Extracts}

The plant specimens were collected, shade dried at room temperature and ground into fine powder using a mechanical blender. Dried powder was then packed in a soxhlet apparatus, extracted with different solvents for 6-8 hours and evaporated under reduced pressure at $40^{\circ} \mathrm{C}-50^{\circ} \mathrm{C}$. The extracts were desiccated and stored in amber glass vials at $4^{\circ} \mathrm{C}$ for future experiments.

\section{Total Phenolic Content (TPC) Analysis}

An in vitro spectrophotometric assay was employed for phenolic determination (Blainski et al., 2013) with few modifications. Folin-ciocalteu reagent was used to quantify total phenolic content of different extracts of three Aconitum species. $20 \mu \mathrm{L}$ of each extract from the stock solution $(10 \mathrm{mg} / \mathrm{mL}$ methanol) was dissolved to $180 \mu \mathrm{L}$ with HPLC methanol. $200 \mu \mathrm{L}$ of Folinciocalteu reagent was added to each sample, mixed thoroughly and incubated at room temperature for $5 \mathrm{~min}$, followed by the addition of $400 \mu \mathrm{L}$ of $20 \%$ (w/v) sodium carbonate. The mixture was then incubated for $20 \mathrm{~min}$ at room temperature in dark and spectral analysis for absorbance was detected at $760 \mathrm{~nm}$. A calibration curve obtained from fivefold concentration of gallic acid was used to quantify the phenolic content of different samples $\left(r^{2}=0.999\right)$. Total phenolic concentration was depicted as $\mathrm{mg}$ of gallic acid equivalent/g calculated from the calibration curve.

\section{Total Flavonoid Content}

For flavonoid determination, an in vitro spectrophotometric assay using aluminium chloride was used (Chang et al., 2002) with few modifications. $30 \mu \mathrm{L}$ of each extract from stock solution $(10 \mathrm{mg} / \mathrm{mL})$ was made up to the volume of $500 \mu \mathrm{L}$ with distilled water. $30 \mu \mathrm{L}$ of $5 \% \mathrm{NaNO}_{2}$ was added followed by the subsequent addition of $300 \mu \mathrm{L}$ of $10 \% \mathrm{AlCl}_{3}$ solution. The sample mixture was incubated for $10 \mathrm{~min}$ at room temperature. With the subsequent addition of $200 \mu \mathrm{L}$ of $1 \mathrm{M} \mathrm{NaOH}$ solution, make up volume of the mixture was adjusted with distilled water. The mixture was allowed to stand for $10 \mathrm{~min}$ and spectral analysis for absorbance was detected at $510 \mathrm{~nm}$. A calibration curve obtained from fivefold concentration of quercetin was used to quantify the flavonoid content of different samples $\left(\mathrm{r}^{2}=0.999\right)$. Total flavonoid concentration was depicted as $\mathrm{mg}$ of quercetin equivalent/g calculated from the calibration curve.

\section{Antioxidant Potential by DPPH Assay}

The DPPH antioxidant capacity of each extract was determined according to the modified method of Brand Williams (Miliauskas et al., 2004). DPPH radicals have an optimal spectral absorbance at $517 \mathrm{~nm}$, which diminishes by the addition of an antioxidant component. A methanolic solution $(1 \mathrm{mg} / 25 \mathrm{~mL})$ of the radical DPPH was freshly prepared and absorbance was recorded to

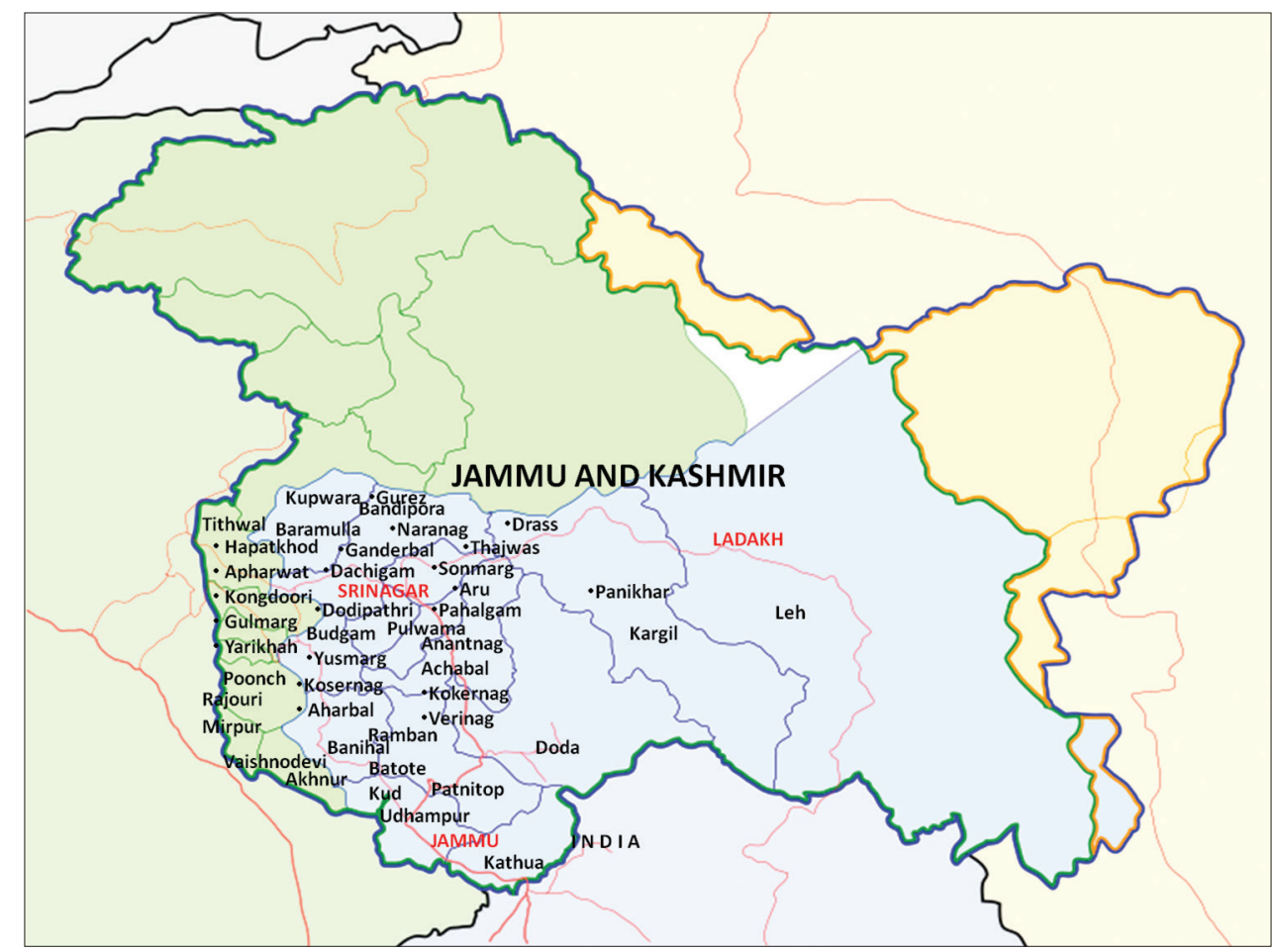

Figure 1: Distribution map of Aconitum species collected from different high altitudinal regions of Kashmir Himalaya 
check the stability of the radical DPPH. Ascorbic acid used as standard was prepared in fivefold concentration to obtain the linear equation. Different concentrations of ascorbic acid were made up to the final volume of $1 \mathrm{~mL}$ with DPPH. The samples were incubated at room temperature in dark for $30 \mathrm{~min}$; spectral analysis for absorbance was done in triplicates and recorded at 517 $\mathrm{nm}$. A linear curve of concentration (ascorbic acid) was plotted against absorbance $\left(\mathrm{r}^{2}=0.994\right)$. Different concentrations of ascorbic acid were assayed in order to check the linearity response and to establish the antioxidant values in the adequate linear range. Same procedure was followed with each plant extract with the varying concentrations and the percentage of scavenging capacity of each extract was calculated from the formula:

$$
\% \text { inhibtion }=\frac{(\mathrm{AB}-\mathrm{AE})}{A B} \times 100
$$

Where, $\mathrm{AB}=$ absorbance of the blank sample, and $\mathrm{AE}=$ absorbance of the plant extract

The $\mathrm{IC}_{50}$ value for antioxidant activity was calculated by plotting the linear graph of percentage of inhibition against the concentration of each extract.

\section{Antimicrobial Potential}

The different extracts of three Aconitum species were screened against six bacteria Klebsiella pneumoniae (ATCC75388), Staphylococcus aureus (MTCC96), Escherichia coli (MTCC730), Bacillus subtilis (MTCC121), Streptococcus pyogenes (MTCC442), Bacillus cereus (IIIM25) and two fungi Saccharomyces cerevisiae (MRCJ-92) and Candida albicans (ATCC90028). The indicator microorganisms were maintained by periodic subculture on Tryptic Soy Agar (TSA) and Potato Dextrose Agar (PDA) and preserved at $4^{\circ} \mathrm{C}$ prior to use. The bacterial and fungal microorganisms were activated on TSA and PDA by incubating at $37^{\circ} \mathrm{C}$ for $18 \mathrm{~h}$ and $48 \mathrm{~h}$, respectively. Inocula were prepared at $1.5 \times 10^{8} \mathrm{CFU} / \mathrm{mL}$ following 0.5 scale of McFarland turbidity standard. Suspensions were diluted at $1.5 \times 10^{6} \mathrm{CFU} / \mathrm{mL}$ and $2.5 \times 10^{4} \mathrm{CFU} / \mathrm{mL}$ for bacteria and fungi, respectively before use. The extracts were initially screened in the micro-well plates at higher concentration of $1000 \mu \mathrm{g} / \mathrm{mL}$. Plates were then incubated at $37^{\circ} \mathrm{C}$ in shaker at $100 \mathrm{rpm}$ for $18 \mathrm{~h}$ and $48 \mathrm{~h}$ for bacteria and fungi, respectively. $40 \mu \mathrm{L}$ of an indicator dye, P-iodonitrotetrazolium chloride (INT), was added to each well containing the test microorganisms (bacteria) and incubated at room temperature for $30 \mathrm{~min}$. The wells containing the test microorganisms and showing inhibitory effect did not affect the INT dye. While the wells which turned pink after treating with INT dye showed no inhibitory effect of extracts against the bacteria. The wells in which precipitation of cells was formed showed no inhibitory effect of extracts against the fungi.

\section{In vitro Determination of Minimum Inhibitory Concentration (MIC)}

The minimal inhibitory concentrations (MIC) of the plant extracts was determined in 96 micro-well sterile plates using microdilution method (Kuete et al., 2008). To $150 \mu \mathrm{L}$ of broth, $50 \mu \mathrm{L}$ of each extract was added and followed by serial dilution with subsequent addition of $100 \mu \mathrm{L}$ of test microorganism. Ciprofloxacin and clotrimoxazole were used as standard antibiotics against bacteria and fungi at concentrations ranging from 0.015 to $2 \mu \mathrm{g} / \mathrm{mL}$ and 0.003 to $0.5 \mu \mathrm{g} / \mathrm{mL}$, respectively. The plates were further incubated at same conditions as previously mentioned. Inhibitory concentration of extracts and standard antibiotics was detected after addition of $40 \mu \mathrm{L}$ of $0.2 \mathrm{mg} / \mathrm{mL}$ of INT dye for bacteria. For fungi, the bottom of the wells was observed for the presence of precipitation of the cells. MIC of extract was considered as the lowest concentration at which there was no visible colour change or no precipitation of cells was observed.

\section{NLRP3 Inflammasome Activation Assay}

The anti-inflammatory effect of different extract was determined by using NLRP3 inflammasome activation assay (Abdullaha et al., 2019). The inhibition of NLRP3 Inflammasome was carried out in mouse macrophages (J774A.1 cells), which were seeded at a density of $0.4 \times 10^{6}$ cells $/ \mathrm{mL}$ per well in 24 well plates overnight. The cells were primed with $1 \mu \mathrm{g} / \mathrm{mL}$ lipopolysaccharide (LPS) for $5 \mathrm{~h}$ and $30 \mathrm{~min}$ which were later treated with different extracts $(10 \mu \mathrm{g})$ for $1 \mathrm{~h}$ in incomplete media. Finally, cells were treated with ATP (3 mM) as a second signal molecule for $30 \mathrm{~min}$. The experiment was terminated by collecting supernatant for ELISA. Cell pellet was lysed with lysis buffer $(0.2 \mathrm{~N} \mathrm{NaOH}+1 \%$ Triton $\mathrm{X})$ for protein estimation. Level of cytokine, IL-1 $\beta$, which is readout for NLRP3 inflammasome activation in cellular supernatant was checked by following mIL-1 $\beta$ ELISA kit (Invitrogen) protocol.

\section{Statistical Analysis}

Experiments were performed in triplicates and expressed as mean \pm SD. Statistical analysis was performed using ANOVA and $P<0.05$ was considered to be significant. Correlations among data obtained were calculated using the MS Excel software.

\section{RESULTS AND DISCUSSION}

\section{Identification and Authentication}

The plant specimens were deposited in the Janaki Ammal Herbarium [CSIR-IIIM, Jammu] and authenticated by comparing with the available specimens of Aconitum by a taxonomist. Proper voucher specimens with their respective accession numbers (23006, 23007 and 23008) were deposited for future reference and record. Some specimens of this genus were also deposited and identified in KASH Herbarium, University of Kashmir with their accession numbers (43273, 43274 and 43275) (Figure 2). Data was collected from different regions of major sampling sites. The survey was extensively conducted during the vegetative/growing period of Aconitum species (flowering to the seed development) based on reported retrospections from herbarium repositories, documented floras, research papers and web interventions. 

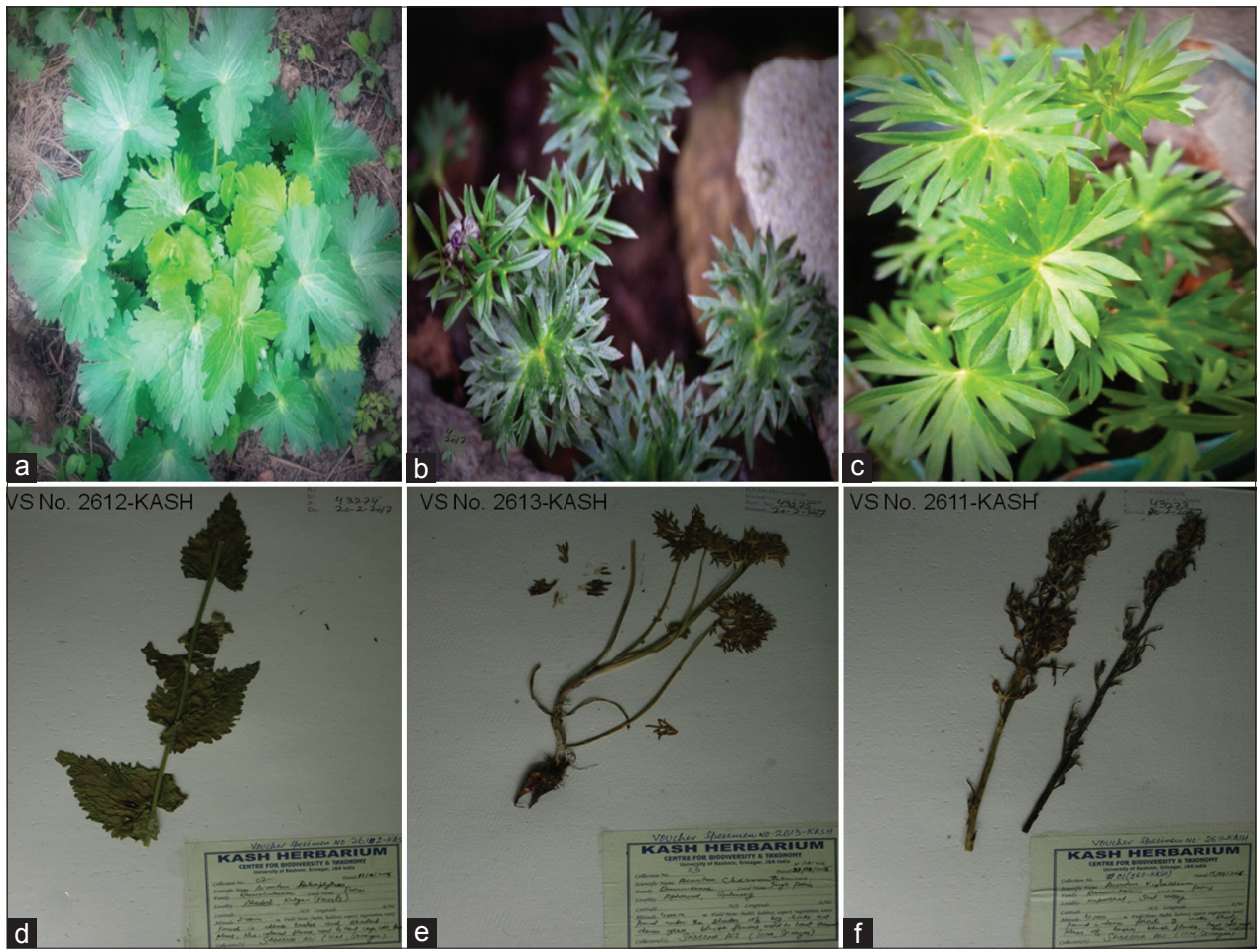

Figure 2: Aconitum species collected from different high altitudinal ecozones of Kashmir Himalaya (a) Aconitum heterophyllum; (b) A. chasmanthum; (c) A. violaceum; (d-f):-Herbarium specimens of (d) A.heterophyllum; (e) A.chasmanthum; (f) A. violaceum.

\section{Traditional Use}

For the last few decades, the arena of herbal medicine has remarkably increased and therefore demands a proper quality control for various medicinal plants used in traditional system of medicine (Nasreen et al., 2010). Traditionally, plants utilized for treating various diseases by folklores have been an ancient practice with traditional insights being transferred to the progenies (Vitalini et al., 2013). Ethnobotanical surveys based on the traditional awareness of medicinal plants have played a vital role on the platforms of various systems of medicine (Heinrich et al., 2009). Such surveys have boosted interest among traditional herbal specialists and research workers for promoting important herbal medicinal plants (Heinrich \& Gibbons, 2001; Leonti, 2011; Pendry et al., 2005; Watkins et al., 2012).

Genus Aconitum, a rich source of diterpene alkaloids and flavanoids is reputed to possess significant pharmaceutical values (Jabeen et al., 2006). The studies on traditional system of medicine have shown that the genus Aconitum has been used in treating various diseases and is considered as a valuable nervine tonic (Dar \& Naqshi, 2001). It has been used as depressant in high arterial tension of cardiac origin (Chopra \& Chopra, 1994). In the present study, ethnopharmacological survey from Kashmir Himalaya was conducted in order to collect traditional knowledge of three Aconitum species with a hope to explore some herbal recipes practised to treat various diseases. During the frequent interviews and questionnaire, it was found that different plant parts are consumed in numerous ways as per folklore practices. Young leaves of Aconitum are either freshly crushed or eaten raw to cure cold, fever, diarrhoea and vomiting.
A mixture of rhizome powder and mustard oil is massaged on the forehead and chest to treat headache and cough. Flower decoction is given to infants to get rid of intestinal worms. The plant juice is consumed to treat urinary infection, respiratory disorders, chest infections and asthma. The rhizome powder is taken to ease joint pain. Roots are boiled in water and consumed to treat abdominal ailments, dysentery, dyspepsia, gastric disorders, intestinal inflammation, malarial fever, piles and throat infection. A cream base paste of crushed tubers and oil is applied to treat skin problems. The leaves of A. heterophyllum are consumed either as raw or in the paste form to treat the common health issues like cough, cold and fever, mostly in children. The rhizome parts of Aconitum heterophyllum are stored in the powder form and used either alone or in mixture with other medicinal plants for treating kidney and bone-joint discomforts, diarrhea, dyspepsia, bronchitis, skin diseases and taken as tonic to increase body stamina. By exploring some more information of the local usage of Aconitum species, it was observed to be the main ingredient of various decoctions and tonics, used by tribal communities of Jammu and Kashmir. The consultation in the wider context from the local Hakeem's of the valley confirmed its ethnomedicinal conventions for treatment of bone related disorders like rheumatism. During mid summer, the aerial parts of non-poisonous species of Aconitum like Aconitum heterophyllum are collected from high altitudes and used as fodder to feed cattle. However, it was found that certain locals from Gujjar and Bakkarwal communities of the areas like Aharbal, Gulmarg, Pahalgam and Gurez regions were quite reluctant to share its traditional usage because all the Aconitum species in the region have been banned for collecting from the wild sources by the State Forest Department. 


\section{Population Size and Distribution}

Kashmir Himalaya is an arc-shaped continuous chain of mountains situated on the Northern boundary of the country, India, between $33^{\circ} .20^{\prime}$ and $34^{\circ} .54^{\prime} \mathrm{N}$ latitudes and from $73^{\circ} .55^{\prime}$ and $75^{\circ} .35^{\prime} \mathrm{E}$ longitudes (Jabeen et al., 2013). Various research findings from past few decades regarding the occurrence of the genus Aconitum from Kashmir Himalayan range has been carried out by various workers with the recent update in the current study (Figure 3). In the present study, the sites of interest were selected by approaching the Herbarium section of Kashmir University, J\&K, where hundreds of Aconitum specimens have been deposited. The locations of the available specimens were noted and accordingly the places of interest were visited for exploring the distributional pattern of genus Aconitum in the region. Various species of Aconitum have been reported from time to time from different ecogeographical ranges of Kashmir Himalaya. During our thorough surveys and investigations, we are reporting presence of three species from new sampling sites which include Yarikhah, Gulmarg, Kangdoori, Apharwat, Khilanmarg, Hapatkhod, Dodpathri, Aharbal, Kausarnag, Dachigam, Naranag, Gurez, Kokernag, Verinag, Ahlan, Pahalgam, Aru, Sonmarg, Thajwas, Drass and Panikhar (Table 1). The distribution pattern of different collected species was plotted by studying various aspects such as populations density, herbivory score, vulnerability score (0-3) and area of occupancy. In account of the ecological field observations, Aconitum was found to grow better in the regions of shady slopes. The species performance in account of the populations found in Gulmarg, Hapatkhod, Gurez and Naranag was found naturally adapted with good population size, while some species were found very scant from the regions like Kangdoori, Apharwat and Sonmarg. In the regions with high disturbance, these three species were found extensively declining (Aharbal, Ahlan, Pahalgam, Aru and Thajwas), while in some other regions like Yarikhah, Dodpathri, Kausarnag, Dachigam, Kokernag, Verinag, Dras \& Panikhar, the species of Aconitum are critically declining (Table 1). Some species of Aconitum which have been examined in the previous studies are entirely vanished from the regions like Jawahar Tunnel, Upper Munda, Lower Munda, Chorwan, Achoor, Khupri, Dahinala, Pir Panjal, Nilnag and Doodganga.

\section{Phytochemical Profiling}

\section{Total Phenolic and Flavonoid Content (TPC \& TFC)}

To prevent the onset of many human ailments including cancer, diabetes and many other metabolic disorders, plant derived phytochemicals have played a significant role. Alone these phytochemicals or in combination with other drug elites, are believed to be bestowed with beneficial effects in treating various metabolic abnormalities, either by inhibiting lipid oxidation, or by exhibiting anti-inflammatory and antimicrobial activities. Antioxidant effect primarily is due to presence of polyphenols which are capable of neutralizing free radicals due to their redox reaction properties (Sen et al., 2010). Polyphenolic compounds have greatly contributed to antioxidant properties but are also potent antimicrobials (Soobrattee et al., 2005; Saleem et al., 2010). The antimicrobial activity of plant phenolics has been extensively studied against human pathogens (Puupponen-Pimiä et al., 2005). Polyphenols have good effects on degenerative diseases and also helps to inhibit the pro-inflammatory responses (Scalbert et al., 2005). A plethora of flavonoids have been reported to contribute for different anti-inflammatory effects (Iacobellis \& Barbaro, 2008). For discovery of novel antiinflammatory drugs, phenolic acid derivatives have played an important role (Silva et al., 2014). These derivatives have been better linked with health management envisaged by both antioxidant and anti-inflammatory effects (Liang \& Kitts, 2016). For instance, ferulic acid has been widely diversified for anti-inflammatory potentials for inhibiting TNF- $\alpha$ and macrophage inflammatory protein-2 production (Sakai et al., 1997; Yang et al., 2013). Keeping in view the importance of phytochemicals of plant sources and their wide use by the local community and practitioners for treating variety of ailments, the present study was attempted to quantify the

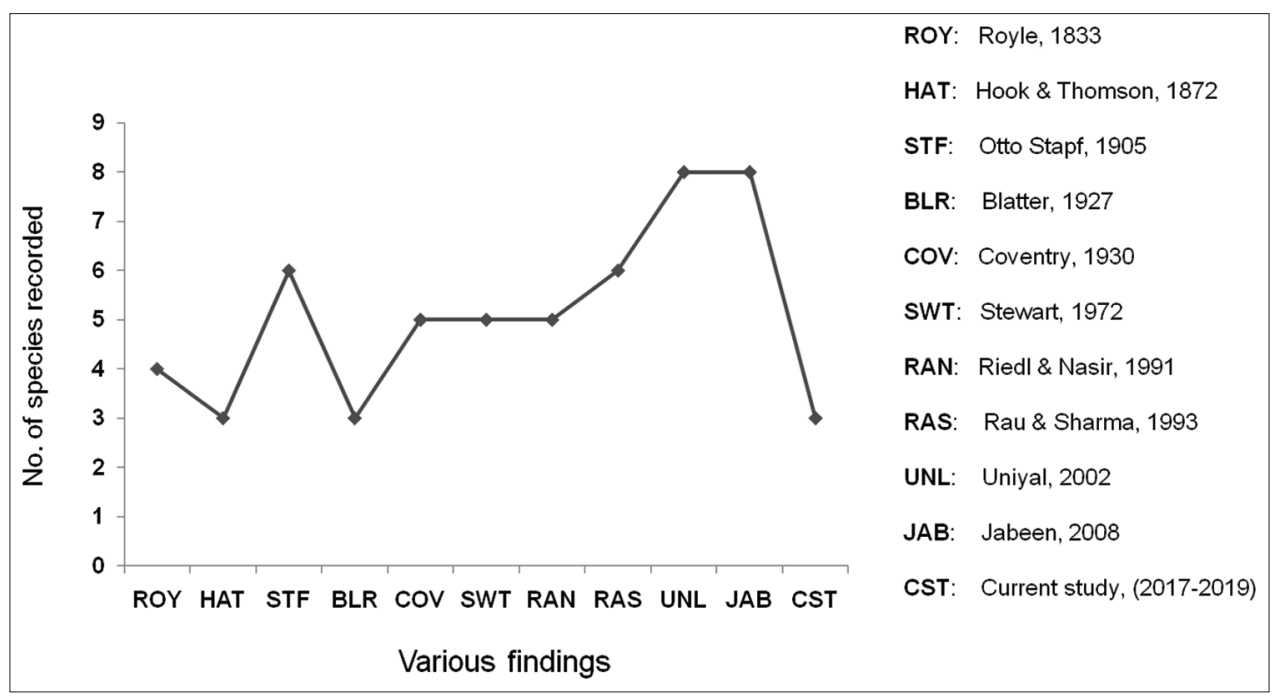

Figure 3: Various findings for occurrence of different species of Aconitum collected from different ecozones of Kashmir Himalaya with recent update 
Table 1: Location, occurrence, co-ordinates, vulnerability-herbivory score of Aconitum species of Kashmir Himalaya; Parameters subjected as " 0 " = not vulnerable; $3 "=$ highly vulnerable; $A 00=$ Area of 0 ccupancy $/ \mathrm{km}^{2}$

\begin{tabular}{|c|c|c|c|c|c|c|c|c|c|c|c|}
\hline Site & Locality or region & Code & $\begin{array}{l}\text { Plant } \\
\text { species }\end{array}$ & $\begin{array}{l}\text { Climate } \\
\text { zone }\end{array}$ & Latitude & Longitude & $\begin{array}{l}\text { Altitude } \\
\text { (m) }\end{array}$ & $\begin{array}{c}\text { No of } \\
\text { populations }\left(1 \mathrm{~km}^{2}\right)\end{array}$ & $\begin{array}{l}\text { Vulnerability } \\
\text { score }\end{array}$ & $\begin{array}{l}\text { Herbivory } \\
\text { score }\end{array}$ & $\mathrm{A} 00 \mathrm{Km}^{2}$ \\
\hline Yarikhah & $\begin{array}{l}\text { Tangmarg } \\
\text { Baramulla }\end{array}$ & YK & A. $\mathrm{H}$ & $\begin{array}{l}\text { Sub } \\
\text { alpine }\end{array}$ & $33^{\circ} 54^{\prime} 40^{\prime \prime}$ & $73^{\circ} 39^{\prime} 21^{\prime \prime}$ & 2035 & $2-4$ & 3 & 3 & 4 \\
\hline Gulmarg & Gulmarg Baramulla & GM & A.C & Alpine & $33^{\circ} 02^{\prime} 56^{\prime \prime}$ & $74^{\circ} 22^{\prime} 46^{\prime \prime}$ & 2722 & $20-25$ & 0 & 0 & 5 \\
\hline Kangdoori & Gulmarg Baramulla & $K D$ & A.C & Alpine & $34^{\circ} 01^{\prime} 34^{\prime \prime}$ & $74^{\circ} 22^{\prime} 46^{\prime \prime}$ & 3058 & $10-15$ & 1 & 1 & 3 \\
\hline Apharwat & Gulmarg Baramulla & AW & A.V & Alpine & $34^{\circ} 02^{\prime} 23^{\prime \prime}$ & $74^{\circ} 22^{\prime} 09^{\prime \prime}$ & 3644 & $12-15$ & 1 & 1 & 12 \\
\hline Khilanmarg & Gulmarg Baramulla & $\mathrm{KM}$ & A.C & Alpine & $34^{\circ} 02^{\prime} 51^{\prime \prime}$ & $74^{\circ} 19^{\prime} 23^{\prime \prime}$ & 2678 & $3-5$ & 3 & 3 & $1-2$ \\
\hline Hapatkhod & Yusmarg Budgam & YM & A.C & $\begin{array}{l}\text { Sub } \\
\text { alpine }\end{array}$ & $34^{\circ} 02^{\prime} 56^{\prime \prime}$ & $74^{\circ} 39^{\prime} 52^{\prime \prime}$ & 2394 & $12-15$ & 1 & 1 & 4 \\
\hline Dodpathri & Dodipathri Budgam & DP & A.H & Alpine & $33^{\circ} 51^{\prime} 03^{\prime \prime}$ & $74^{\circ} 33^{\prime} 47^{\prime \prime}$ & 2787 & $2-6$ & 3 & 3 & 4 \\
\hline Aharbal & Aharbal Kulgam & $A B$ & A, $\mathrm{H}$ & $\begin{array}{l}\text { Sub- } \\
\text { alpine }\end{array}$ & $33^{\circ} 38^{\prime} 43^{\prime \prime}$ & $74^{\circ} 46^{\prime} 48^{\prime \prime}$ & 2262 & $8-10$ & 2 & 2 & 5 \\
\hline Kosernag & $\begin{array}{l}\text { Kosernag } \\
\text { Kulgam }\end{array}$ & $\mathrm{KS}$ & A. $H$ & Alpine & $33^{\circ} 30^{\prime} 02^{\prime \prime}$ & $74^{\circ} 50^{\prime} 03^{\prime \prime}$ & 3681 & $4-6$ & 3 & 3 & 4 \\
\hline Dachigam & Harwan Srinagar & $D G$ & A.H & $\begin{array}{l}\text { Sub } \\
\text { alpine }\end{array}$ & $34^{\circ} 08^{\prime} 14^{\prime \prime}$ & $75^{\circ} 02^{\prime} 15^{\prime \prime}$ & 2913 & $4-8$ & 3 & 3 & 5 \\
\hline Naranag & Naranag Ganderbal & $N G$ & A.H & $\begin{array}{l}\text { Sub } \\
\text { alpine }\end{array}$ & $34^{\circ} 21^{\prime} 16^{\prime \prime}$ & $74^{\circ} 58^{\prime} 43^{\prime \prime}$ & 2260 & $14-18$ & 0 & 0 & 6 \\
\hline Gurez & Gurez Bandipora & $G Z$ & A.C & $\begin{array}{l}\text { Sub } \\
\text { alpine }\end{array}$ & $34^{\circ} 39^{\prime} 27^{\prime \prime}$ & $74^{\circ} 44^{\prime} 06^{\prime \prime}$ & 2656 & $15-20$ & 0 & 0 & 7 \\
\hline Kokernag & Kokernag Anantnag & $\mathrm{KN}$ & A.H & $\begin{array}{l}\text { Sub } \\
\text { alpine }\end{array}$ & $33^{\circ} 35^{\prime} 05^{\prime \prime}$ & $78^{\circ} 18^{\prime} 14^{\prime \prime}$ & 1939 & $3-6$ & 3 & 3 & 4 \\
\hline Verinag & Verinag Anantnag & VN & A. H & Alpine & $33^{\circ} 32^{\prime} 17^{\prime \prime}$ & $75^{\circ} 16^{\prime} 19^{\prime \prime}$ & 1878 & $4-6$ & 3 & 3 & 3 \\
\hline Ahlan & Ahlan Anantnag & $A L$ & A. $\mathrm{H}$ & $\begin{array}{l}\text { Sub } \\
\text { alpine }\end{array}$ & $33^{\circ} 29^{\prime} 52^{\prime \prime}$ & $75^{\circ} 23^{\prime} 00^{\prime \prime}$ & 2387 & $8-10$ & 2 & 2 & 2 \\
\hline Pahalgam & Pahalgam Anantnag & $P G$ & A. H & Alpine & $34^{\circ} 00^{\prime} 58^{\prime \prime}$ & $75^{\circ} 18^{\prime} 41^{\prime \prime}$ & 2178 & $7-9$ & 2 & 2 & 6 \\
\hline Aru & Pahalgam Anantnag & AR & A.H & Alpine & $34^{\circ} 05^{\prime} 44^{\prime \prime}$ & $75^{\circ} 15^{\prime} 4^{\prime \prime} 6$ & 2512 & $6-8$ & 2 & 2 & 4 \\
\hline Sonmarg & Sonmarg Ganderbal & SM & A. $\mathrm{H}$ & Alpine & $34^{\circ} 18^{\prime} 10^{\prime \prime}$ & $75^{\circ} 17^{\prime} 38^{\prime \prime}$ & 2664 & $5-6$ & 2 & 2 & 5 \\
\hline Thajwas & Thajwas Ganderbal & TJ & A. $\mathrm{H}$ & Alpine & $34^{\circ} 16^{\prime} 37^{\prime \prime}$ & $75^{\circ} 17^{\prime} 04^{\prime \prime}$ & 2989 & $7-8$ & 2 & 2 & 3 \\
\hline Drass & Drass Kargil & DR & A.V & Alpine & $34^{\circ} 25^{\prime} 45^{\prime \prime}$ & $75^{\circ} 44^{\prime} 53^{\prime \prime}$ & 3085 & $2-3$ & 3 & 3 & 3 \\
\hline Panikhar & $\begin{array}{l}\text { Panikhar } \\
\text { Kargil }\end{array}$ & PK & A.V & $\begin{array}{l}\text { Sub } \\
\text { alpine }\end{array}$ & $34^{\circ} 07^{\prime} 16^{\prime \prime}$ & $7557^{\prime} 21^{\prime \prime}$ & 3246 & $2-3$ & 3 & 3 & 3 \\
\hline
\end{tabular}

Plant Species: $\mathrm{A} . \mathrm{H}=$ Aconitum heterophyllum; $\mathrm{A} . \mathrm{C}=$ Aconitum chasmanthum and $\mathrm{A} . \mathrm{V}=$ Aconitum violaceum

phytochemicals (phenolics and flavonoids) from different extracts of three Aconitum species.

The results of phytochemical quantification were retrieved with a wide variation of phenolic and flavonoid concentrations in different extracts of Aconitum species analyzed. The total phenolic concentration varied from 0.185 to $2.188 \mathrm{mg} \mathrm{GAE} / \mathrm{g}$ of sample. Methanolic extracts of A. heterophyllum and A. chasmanthum showed a high phenolic content of 1.193 \& $2.188 \mathrm{mg} \mathrm{GAE} / \mathrm{g}$, respectively. The total flavonoid concentration ranged from lowest in ethyl acetate extract of A. chasmanthum $(0.144 \mathrm{mg} \mathrm{QE} / \mathrm{g})$ to the highest in methanolic extract of A. chasmanthum $(2.196 \mathrm{mg} \mathrm{QE} / \mathrm{g})$. Determination of total phenolic and total flavonoid content was aided by using gallic acid and quercetin as standards. Calibration curve equations obtained were y $=0.625+0.078\left(\mathrm{r}^{2}=0.999\right)$ and $\mathrm{y}=0.017 \mathrm{x}+$ $0.044\left(\mathrm{r}^{2}=0.999\right)$, respectively (Table 2$)$. The results obtained during the study provided a scientific baseline in knowing the quantities of these phytochemicals (phenolics and flavonoids) in different extracts of three Aconitum species.

\section{Antioxidant Capacity}

Most of the plant species and herbs of medicinal importance have significantly contributed to the excellent antioxidant potentials globally (Krishnaiah et al., 2011). The secondary metabolites such as phenolics and flavonoids play an important role as antioxidants in controlling different human diseases. These are a kind of natural products and antioxidant substances that protect human, animal and plant cells against damaging effects of free radicals (Kukić et al., 2006). Nowadays most of the life threatening diseases including neurodegenerative and cardiovascular disease, oxidative stress have been considered as a main resourceful factor. Researchers have shown that the antioxidants of plant origin with free-radical scavenging properties could have enormous importance as therapeutic agents in diseases caused due to oxidative stress (Ramchoun et al., 2009). In addition, the introduction of antioxidants have been proved to be an encouraging method to encounter the effects of oxidative stress (Kasote et al., 2013).

In the present study, DPPH antioxidant assay was employed to evaluate the antioxidant potential of crude extracts of three Aconitum species. Determination of antioxidant efficiency was aided by use of ascorbic acid as standard, where the calibration curve equation obtained was $y=-112.6 \mathrm{x}+0.942\left(\mathrm{r}^{2}=0.994\right)$. DPPH radical scavenging activities of plant extracts varied from $25.09 \%$ to $80.115 \%$, which approximately produced fourfold variation. Methanolic extract of A. chasmanthum represented significant antioxidant capacity (80.115\%) in DPPH assay, 
Ali et al.

Table 2: Measurement of total phenolic and total flavonoid content and antioxidant activity in different extracts of three Aconitum species

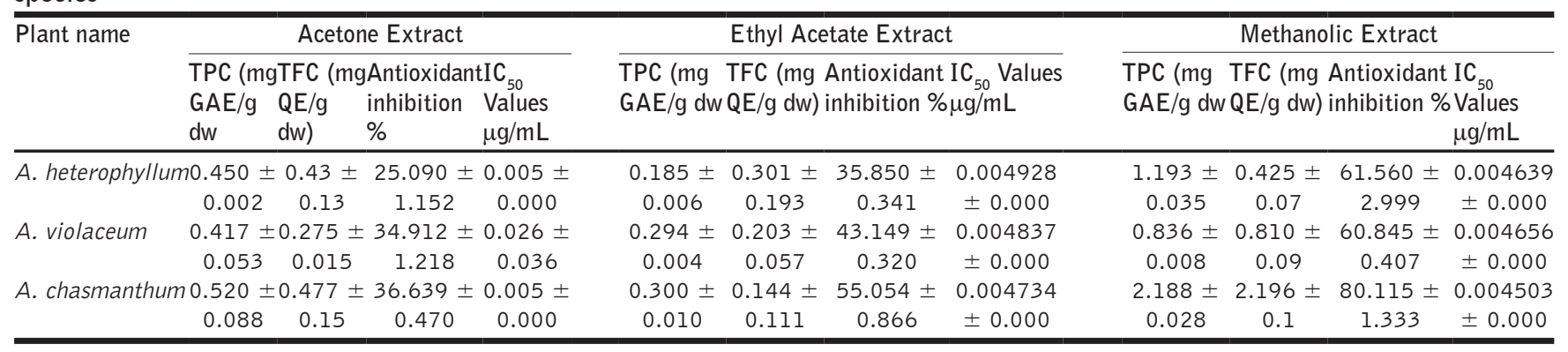

followed by methanolic extract of A. heterophyllum (61.560\%). The acetone extract of A. heterophyllum showed the lowest antioxidant potential of $25.09 \%$ inhibition. The scavenging capacity of the DPPH radical by ethyl extract of A. heterophyllum was found to be higher $\left[\mathrm{IC}_{50}\right.$ value of $\left.49.28 \pm 0.00 \mu \mathrm{g} / \mathrm{mL}\right]$.

\section{Correlation between TPC, TFC and Antioxidant Potential}

Regression analysis was performed by correlating the results obtained with different methods. Significant correlations were found between various quantification methods with respect to the antioxidant potential, expressed as linear calibration curve. Significant correlation of DPPH assay with respect to the total phenolic content was obtained $\left(r^{2}=0.976\right)$. Likewise, a good correlation with respect to the total flavonoid content was also obtained $\left(\mathrm{r}^{2}=0.914\right)$. The variation in the chemical profiles of different extracts has accounted for significant antioxidant activities shown in Table 2.

\section{Antimicrobial Potential}

The tremendous throughputs of herbal drugs for treating the broad spectrum human ailments either directly or in the form of crude extracts or natural products or their semi-synthetic derivatives has indeed contributed to pharmacopeia extensively (Houghton, 2000). But somehow bioassay guided fractionation and isolation of active metabolites sometimes loses the synergetic effects of metabolites against various microbes. This demands standardization of plant extracts as an approach in treating various microbial infections (Njimoh et al., 2015). Plant extracts have been widely explored as key element in traditional folk medicine to treat microbial infections and also constitute sources of conventional antimicrobials (Nawab et al., 2011). The preliminary phytochemical screening of plant extracts have greatly contributed to the antimicrobial potentials (Tariq et al., 2011; Malik et al., 2011). Owing to the ability of phenolics and flavonoids to interact with cellular enzymes, destabilize cellular membranes and inhibit cell cycle progression, these phytochemicals often exhibit antimicrobial activity (Sen \& Batra, 2012; Pisoschi et al., 2018).

In the present study, antimicrobial activity of different extracts of three Aconitum species used in folk medicine were screened in vitro against eight microbial strains and their activities were determined by MIC values, depicted in Table 3. According to the results obtained, extracts of the plant species showed antimicrobial activities against one or more bacterial strains and the fungal species tested. The antimicrobial activities of plant extracts were correlated with standard antibiotics such as ciprofloxacin and clotrimoxazole, which were used as positive controls. It has been reported that activities of plant extracts are significant when MIC $\leq 0.1 \mathrm{mg} /$ $\mathrm{mL}$, moderate when $0.1<$ MIC $\leq 0.625 \mathrm{mg} / \mathrm{mL}$, weak when MIC $>0.625 \mathrm{mg} / \mathrm{mL}$, according to the scale of sensitivity of plant extracts (Kuete et al., 2008). The sensitivity of each individual microorganism depends on extract type and the solvent used for extraction. Each individual extract showed a moderate inhibition potential on at least one indicator microorganism. The methanol and dichloromethane extract of A. chasmanthum exhibited moderate antimicrobial activity than the other extracts with MIC value $0.125 \mathrm{mg} / \mathrm{mL}$ against Candida albicans and Streptococcus pyogenes, respectively. Methanolic and aqueous extract of A. heterophyllum and A. violaceum also showed similar activity against Bacillus subtilis and Candida albicans, $(\mathrm{MIC}=0.125 \mathrm{mg} / \mathrm{mL}$ ), respectively. Only Bacillus cereus was not inhibited by any of the extracts of A. violaceum while all the extracts from the three plant species showed moderate anti-fungal effect against C. albicans. Most of the extracts inhibited the growth at less than $1 \mathrm{mg} / \mathrm{mL}$. However, none of the extracts inhibited the growth of E.coli and Bacillus cereus possibly due to the complexities in the cell wall (Li \& Nikaido, 2009). The presence of cell wall in some microorganisms tends to block the passage of inhibitors and is generally more difficult to inhibit (Nikaido, 2003). In the present study, the methanolic extract of A. heterophyllum and A. chasmanthum have shown activity against the gram positive bacteria Bacillus subtilis and Streptococcus pyogenes, respectively. Whereas, extracts of A. violaceum and A. chasmanthum have shown antimicrobial activity against gram negative bacteria, Klebsiella pneumonia and E.coli at high concentration $(1 \mathrm{mg} / \mathrm{mL})$, respectively. None of the extracts of A. heterophyllum have shown antimicrobial effect against any gram negative bacteria. The results of the present study are in due agreement, demonstrating the antimicrobial potential of extracts of three Aconitum species and therefore, can be suitable candidates for discovering narrow spectrum antibiotics against different microorganisms. The specific indications claimed by the traditional healers are confirmed by the antimicrobial screening of three Aconitum 
Table 3: Antimicrobial potential of different extracts of three Aconitum species (MIC in $\mathrm{mg} / \mathrm{ml}$ )

\begin{tabular}{|c|c|c|c|c|c|c|c|c|c|c|c|}
\hline \multirow[t]{2}{*}{ Pathogen } & \multirow[t]{2}{*}{ Plant Name } & \multicolumn{8}{|c|}{ Extract } & \multicolumn{2}{|c|}{ Standard antibiotics } \\
\hline & & Acetone & Chloroform & Hexane & $\mathrm{DCM}$ & E. Acetate & Methanol & Ethanol & $\overline{\text { Aqueous }}$ & Ciprofloxacin & $\overline{\text { Clotrimoxazole }}$ \\
\hline $\mathrm{KP}$ & A.heterophyllum & - & 1.0 & 1.0 & - & - & - & - & 1.0 & 0.007 & / \\
\hline EC & & - & - & - & - & - & - & - & - & $<0.003$ & l \\
\hline BS & & - & - & 0.250 & - & - & 0.125 & - & 0.250 & 0.062 & / \\
\hline SP & & 0.250 & - & - & - & - & 0.5 & - & 0.250 & 00.31 & l \\
\hline$B C$ & & - & - & - & - & - & - & - & 0.250 & 0.062 & / \\
\hline SA & & 1.0 & 1.0 & 1.0 & 1.0 & - & 1.0 & - & 1.0 & 0.031 & / \\
\hline SC & & 0.5 & - & 0.5 & - & - & - & 1.0 & - & I & 0.140 \\
\hline CA & & 0.250 & 0.5 & 0.250 & 0.5 & 0.5 & 0.5 & 0.5 & 0.5 & l & 0.035 \\
\hline $\mathrm{KP}$ & A.violaceum & - & - & - & - & 1.0 & - & 1.0 & 1.0 & 0.007 & / \\
\hline $\mathrm{EC}$ & & 1.0 & 1.0 & - & - & 1.0 & - & - & 1.0 & $<0.003$ & / \\
\hline BS & & 0.5 & 1.0 & - & 1.0 & 1.0 & 0.5 & 1.0 & - & 0.062 & / \\
\hline SP & & - & 1.0 & - & - & - & - & - & - & 00.31 & / \\
\hline$B C$ & & - & - & - & - & - & - & - & - & 0.062 & / \\
\hline SA & & 1.0 & 1.0 & - & 1.0 & 1.0 & 1.0 & - & 1.0 & 0.031 & / \\
\hline SC & & - & 0.5 & - & - & - & - & - & - & / & 0.140 \\
\hline CA & & 0.5 & 0.5 & 0.5 & 0.5 & 0.5 & 0.5 & 0.5 & 0.125 & / & 0.035 \\
\hline $\mathrm{KP}$ & A. chasmanthum & - & - & - & - & - & 1.0 & 1.0 & - & 0.007 & / \\
\hline $\mathrm{EC}$ & & - & - & - & - & - & 1.0 & 1.0 & 1.0 & $<0.003$ & / \\
\hline BS & & 1.0 & - & 0.250 & 0.250 & 0.5 & 0.5 & 1.0 & 0.5 & 0.062 & / \\
\hline SP & & - & - & 0.5 & 0.5 & - & 0.125 & 0.5 & 0.5 & 00.31 & / \\
\hline$B C$ & & - & - & 0.250 & 0.250 & - & - & - & 0.250 & 0.062 & / \\
\hline SA & & 1.0 & - & - & 1.0 & 1.0 & 1.0 & 1.0 & 1.0 & 0.031 & / \\
\hline SC & & - & 1.0 & - & - & 1.0 & - & - & 0.5 & I & 0.140 \\
\hline CA & & 0.5 & 0.5 & 0.5 & 0.125 & 0.5 & 0.5 & 0.5 & 0.5 & I & 0.035 \\
\hline
\end{tabular}

$\mathrm{KP}=($ Klebsiella pneumoniae (ATCC75388); $\mathrm{EC}=$ Escherichia coli $(\mathrm{MTCC} 730) ; \mathrm{BS}=$ Bacillus subtilis $(\mathrm{MTCC} 121) ; \mathrm{SP}=$ Streptococcus pyogenes (MTCC442); BC= Bacillus cereus (IIIM25); SA= Staphylococcus aureus (MTCC96); SC= Saccharomyces cerevisiae (MRCJ-92); CA= Candida albicans (ATCC90028)

species which could also provide the scientific basis in treating the microbial infections.

\section{Anti-inflammatory Potential}

The inflammatory process as a defense mechanism in the body is a beneficial immune response to foreign challenges or tissue injury, ultimately leading to the restoration (Lawrence et al., 2002). During infection and disease development, macrophages are an important component and play important roles in human immune defense system (Schluger and Rom, 1998). Macrophages employed for inflammasome activation initiate the inflammatory responses by releasing the pro-inflammatory cytokines IL-1 $\beta$ which provides additional immune cells to the sites of infection (Boscá et al., 2005). The inflammasome inhibition method has become the choice of the in vitro antiinflammatory tests involving acetylcholinesterase, lipoxygenase and cyclooxygenase (Akula \& Odhav, 2008; Rathinam \& Fitzgerald, 2016; Oguntoye et al., 2018; Abdullaha et al., 2019). Inflammasomes are the most wide studied multimeric complexes involved in various auto-inflammatory and autoimmune diseases such as respiratory illness, atherosclerosis, Alzheimer's disease, diabetes, rheumatoid arthritis and skin diseases (Manzi \& Wasko, 2000; Tak \& Firestein, 2001; Heneka et al., 2013; Simpson et al., 2014; Fenini et al., 2017). Inflammasomes upregulate the levels of cytokines (IL-1 $\beta$ ) through activation of caspase-1 enzyme (Madouri et al., 2015; Liu \& Lin, 2017). The potential of plant extracts to serve as safer and effective therapeutic agents has gained attention to act as multi-effective anti-inflammatory leads. Therefore, the present study was aimed to gather information of Aconitum species used for treating human ailments mostly rheumatoid arthritis and thereby executing NLRP3 inflammasomes inhibitory properties of Aconitum species in the hope to suggest new baseline for the discovery of potential drug candidates.

Given the importance of the NLRP3 inflammasome, we have established a screening assay for antiinflammatory potential of different extracts of Aconitum species that target the NLRP3 inflammasome signalling. LPS and ATP treatment of J774A.1 derived macrophages induce the activation of NLRP3 (Abdullaha et al., 2019). After priming J774A.l macrophage cells with lipopolysaccharides (LPS) and activation with ATP signal molecule and challenged against different extracts of three Aconitum species, the inhibition of NLRP inflammasome was found significant in the ethyl acetate extract of A. violaceum with the percent inhibition of inflammation as $74.61 \%$ followed by the ethyl acetate extract of A. chasmanthum (69.55\%) at a concentration of $10 \mu \mathrm{g} / \mathrm{ml}$ each. The comparative inhibition of NLRP inflammasome by different extracts of three Aconitum species is depicted by an error bar graph (Figure 4)

During our study, the extracts exhibiting the strong potential combating against the inflammation can also prove as strong candidates for the discovery of new active compounds involved in the NLRP3 inflammasome regulation. Plant extracts of Aconitum source thus can be regarded to hit multiple targets which may result in better activities than the effect of individual metabolites, thereby reviving the synergism of the plant extracts. 


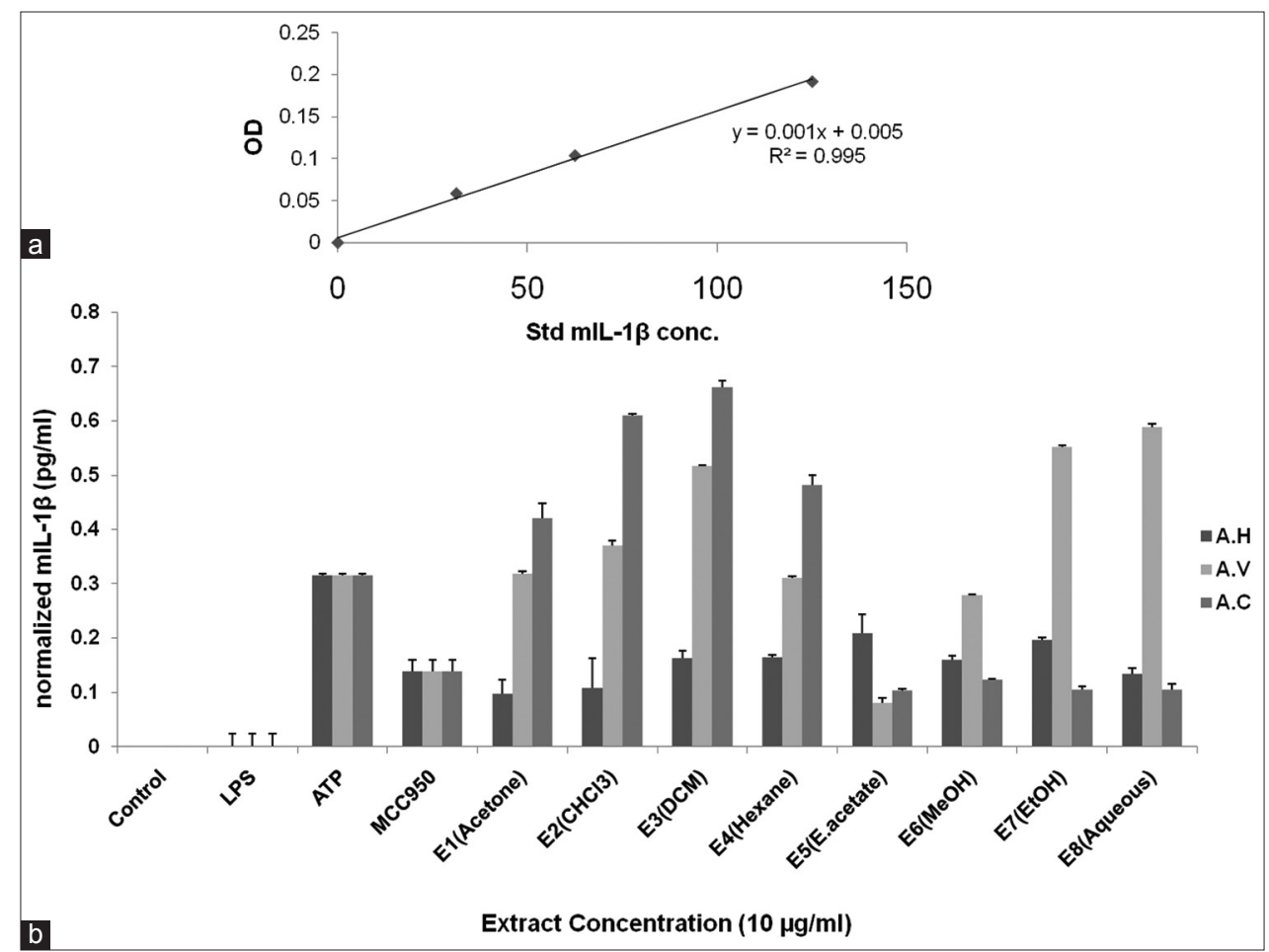

Figure 4: Inhibition of NLRP3 inflammasome: Anti-inflammatory effect of different solvent extracts of Aconitum species on IL-1 $\beta$ production and secretion in LPS-primed and ATP-stimulated (J774A.1) macrophage cells. (El=acetone extract; E2=chloroform extract; E3=dichloromethane extract; $\mathrm{E} 4=$ hexane extract; $\mathrm{E} 5=$ =thyl acetate extract $\mathrm{E} 6=$ methanol extract; $\mathrm{E} 7=$ ethanol extract and $\mathrm{E} 8=$ aqueous extract).

\section{CONCLUSION}

The present study provided an insight into the dwindling status of genus Aconitum from this region. The study revealed that Aconitum species are alarmingly declining from Kashmir Himalaya and some species being entirely vanished from the regions like Doodganga, Jawahar Tunnel, Upper Munda, Lower Munda, Chorwan Achoor, Khupri, Dahinala, Pir Panjal and Nilnag. As such the genus demands significant endeavours for its germplasm characterization, agrotechnology development and captive cultivation which are a prerequisite for its conservation. Our experimental investigation indicated that Aconitum chasmanthum could be useful to prevent free radical production which causes deadly diseases such as atherosclerosis, cancers and ageing. These species could also be used employed to treat microbial infections caused by Streptococcus pyogenes, Bacillus subtilis and Candida albicans. In addition, the results highlighted that Aconitum violaceum could be used as powerful anti-inflammatory agent to treat bone joint disorders such as rheumatoid arthritis. In conclusion, the present study could provide a scientific basis for the traditional use of Aconitum possibly leading to relatively inexpensive, effective, and safe therapies either as herbal/botanical products or through discovery of bioactive and safe natural products/semi synthetic derivatives.

\section{ACKNOWLEDGEMENT}

The work was a part of the Women Scientist-A project funded by Department of Science and Technology (DST), New Delhi,
Govt. of India, awarded to SA. AN is thankful to TWAS-CSIR fellowship. DK is indebted to CSIR for SRF and NK is supported by ICMR for SRF. PS, SGG and QPH are thankful for funding from CSIR Phytopharma Mission (HCP0010).

\section{AUTHOR CONTRIBUTIONS}

SA has majorly contributed in executing the whole research work and writing the manuscript. AN helped in antimicrobial evaluation. DK and AK helped in inflammasome activation assay. PS, QPH and SGG has analyzed the results and proofread the manuscript and figures/tables.

\section{REFERENCES}

Abdullaha, M., Mohammed, S., Ali, M., Kumar, A., Vishwakarma, R. A., \& Bharate, S. B. (2019). Discovery of quinazolin-4 (3 H)-ones as NLRP3 inflammasome inhibitors: computational design, metal-free synthesis, and in vitro biological evaluation. The Journal of Organic Chemistry, 84, 5129-5140. https://doi.org/10.1021/acs.joc.9b00138

Akula, U. S. \& Odhav, B. (2008). In vitro 5-lipoxygenase inhibition of polyphenolic antioxidants from undomesticated plants of South Africa. Journal of Medicinal Plants Research, 2, 207-212.

Balakrishnan, N. P., Rao, R. R., \& Hajra, P. K. (1993). Flora of India (Vol. 1, pp. 1-45). In B. D. Sharma (Ed.). Calcutta: Botanical Survey of India.

Blainski, A., Lopes, G. C., \& De Mello, J. C. P. (2013). Application and analysis of the folin ciocalteu method for the determination of the total phenolic content from Limonium brasiliense L. Molecules, 18, 6852-65. https://doi.org/10.3390/molecules18066852

Boscá, L., Zeini, M., Través, P. G., \& Hortelano, S. (2005). Nitric oxide and cell viability in inflammatory cells: A role for NO in macrophage function and fate. Toxicology, 208, 249-258. https://doi.org/10.1016/j. tox.2004.11.035

Chang, C.-C., Yang, M.-H., Wen, H.-M. \& Chern, J.-C. (2002). Estimation of 
total flavonoid content in propolis by two complementary colometric methods. Journal of Food and Drug Analysis, 10, 178-182. https:// doi.org/10.38212/2224-6614.2748

Chhetree, R.R., Dash, G.K., Mondal, S. \& Acharyya, S. (2010). Studies on the hypoglycaemic activity of Aconitum napellus I. roots. Drug Invention Today, 2, 343-346.

Chopra, R.N. \& Chopra, I.C. (1994). Indigenous drugs of India. Jaipur, India: Academic Publishers.

Coventry, B.O. (1930). Wild flowers of Kashmir. Raithby, Lawrence and Co., London.

Dar, G. H., \& Naqshi, A. R. (2001). Threatened flowering plants of the Kashmir Himalaya-a checklist. Oriental Science, 6(1), 23-53.

Fenini, G., Contassot, E., \& French, L. E. (2017). Potential of IL-1, IL-18 and inflammasome inhibition for the treatment of inflammatory skin diseases. Frontiers in Pharmacology, 8, 278. https://doi.org/10.3389/ fphar.2017.00278

Heinrich, M., \& Gibbons, S. (2001). Ethnopharmacology in drug discovery: an analysis of its role and potential contribution. Journal of Pharmacy and Pharmacology, 53(4), 425-432. https://doi. org/10.1211/0022357011775712

Heinrich, M., Edwards, S., Moerman, D. E., \& Leonti, M. (2009). Ethnopharmacological field studies: a critical assessment of their conceptual basis and methods. Journal of Ethnopharmacology, 124(1), 1-17. https://doi.org/10.1016/j.jep.2009.03.043

Heneka, M. T., Kummer, M. P., Stutz, A., Delekate, A., Schwartz, S., VieiraSaecker, A., Griep, A., Axt, D., Remus, A., Tzeng, T.C., Gelpi, E. Halle, A., Korte, M., Latz, E., \& Golenbock, D.T. (2013). NLRP3 is activated in Alzheimer's disease and contributes to pathology in APP/PS1 mice. Nature, 493(7434), 674-678. https://doi:10.1038/ nature11729

Houghton, P. J. (2000). Chemistry and biological activity of natural and semisynthetic chromone alkaloids. Studies in Natural Products Chemistry, 21, 123-155. https://doi.org/10.1016/S1572-5995(00)80005-8

lacobellis, G., \& Barbaro, G. (2008). The double role of epicardial adipose tissue as pro-and anti-inflammatory organ. Hormone and Metabolic Research, 40(07), 442-445. https://doi.org/10.1055/s-2008-1062724

Jabeen, N., Kozgar, M. I., Dar, G. H., Shawl, A. S., \& Khan, S. (2013). Distribution and Taxonomy of Genus Aconitum in Kashmir: Potent Medicinal Resource of Himalayan Valley. Chiang Mai Journal of Science, 40(2), 173-186.

Jabeen, N., Shawl, A. S., Dar, G. H., Jan, A., \& Sultan, P. (2006). Callus induction and organogenesis from explants of Aconitum heterophyllum medicinal plant. Biotechnology, 5(3), 287-291. https:// doi.org/10.3923/biotech.2006.287.291

Kasote, D. M., Hegde, M. V., \& Katyare, S. S. (2013). Mitochondrial dysfunction in psychiatric and neurological diseases: cause (s), consequence (s), and implications of antioxidant therapy. Biofactors, 39(4), 392-406. https://doi.org/10.1002/biof.1093

Kaul, M. K. (1997). Medicinal plants of Kashmir and Ladakh: Temperate and cold arid Himalaya. New Delhi, India: Indus Publishing.

Khan, Z. S., Khuroo, A. A., \& Dar, G. H. (2004). Ethnomedicinal survey of Uri, Kashmir Himalaya. Indian Journal of Traditional Knowledge. 3(4), 351-357.

Krishnaiah, D., Sarbatly, R., \& Nithyanandam, R. (2011). A review of the antioxidant potential of medicinal plant species. Food and Bioproducts Processing, 89(3), 217-233. https://doi.org/10.1016/j. fbp.2010.04.008

Kuete, V., Wansi, J. D., Mbaveng, A. T., Sop, M. K., Tadjong, A. T., Beng, V. P. Etoa, F.X., Wandji, J., Meyer, J.M., Lall, N. (2008). Antimicrobial activity of the methanolic extract and compounds from Teclea afzelii (Rutaceae). South African Journal of Botany, 74(4), 572-576. https:// doi.org/10.1016/j.sajb.2008.02.004

Kukić, J., Petrović, S., \& Niketić, M. (2006). Antioxidant activity of four endemic Stachys taxa. Biological and Pharmaceutical Bulletin, 29(4), 725-729. https://doi.org/10.1248/bpb.29.725

Lawrence, T., Willoughby, D. A., \& Gilroy, D. W. (2002). Anti-inflammatory lipid mediators and insights into the resolution of inflammation. Nature Reviews Immunology, 2(10), 787-795. https://doi.org/10.1038/nri915

Leonti, M. (2011). The future is written: impact of scripts on the cognition, selection, knowledge and transmission of medicinal plant use and its implications for ethnobotany and ethnopharmacology. Journal of Ethnopharmacology, 134(3), 542-555. https://doi.org/10.1016/j. jep.2011.01.017

Li, X. Z., \& Nikaido, H. (2009). Efflux-mediated drug resistance in bacteria. Drugs, 69(12), 1555-1623.
Liang, N., \& Kitts, D. D. (2016). Role of chlorogenic acids in controlling oxidative and inflammatory stress conditions. Nutrients, 8(1), 1-20. https://doi.org/10.3390/nu8010016

Liangqian, L., \& Kadota.Y. (2001). Aconitum L. In: Wu, Z.Y., Raven, P.H. (Eds.), Flora of China. Beijing, China: Science Press.

Liu, M. H., \& Lin, X. L. (2017). Pharmacological Use of NLRP3 Inflammasome Inhibitors: Novel Intervention Strategies in Diabetes-Associated Vascular Complications. Journal of Advanced Therapies and Medical Innovation Sciences, 2, 35-36

Lone, F. A., Lone, S., Aziz, M. A., \& Malla, F. A. (2012). Ethnobotanical studies in the tribal areas of district Kupwara, Kashmir. International Journal of Pharma and Bio Sciences, 3(4), 399-411.

Lone, S. A., Mushtaq, S., Hassan, Q. P., \& Gupta, S. (2018). Dwindling status of Epimedium elatum (Morren \& Decne) and its geographical distribution in Kashmir Himalaya, India. Current Botany, 9, 47-52.

Madouri, F., Guillou, N., Fauconnier, L., Marchiol, T., Rouxel, N., Chenuet, P., Ledru, A., Apetoh, L., Ghiringhelli, F., Chamaillard, M., Zheng, S.G. Trovero, F., Quesniaux, V. F. J., Ryffel, B., \& Togbe, D. (2015). Caspase-1 activation by NLRP3 inflammasome dampens IL-33-dependent house dust mite-induced allergic lung inflammation. Journal of Molecular Cel/ Biology, 7(4), 351-365. https://doi.org/10.1093/jmcb/mjv012

Malik, F., Hussain, S., Mirza, T., Hameed, A., Ahmad, S., Riaz, H., Shah, P.A. \& Usmanghani, K. (2011). Screening for antimicrobial activity of thirtythree medicinal plants used in the traditional system of medicine in Pakistan. Journal of Medicinal Plants Research, 5(14), 3052-3060.

Manzi, S., \& Wasko, M. C. M. (2000). Inflammation-mediated rheumatic diseases and atherosclerosis. Annals of the rheumatic diseases, 59(5), 321-325.

Miliauskas, G., Venskutonis, P. R., \& Van Beek, T. A. (2004). Screening of radical scavenging activity of some medicinal and aromatic plant extracts. Food Chemistry, 85(2), 231-237. https://doi.org/10.1016/j. foodchem.2003.05.007

Nasreen, S., Radha, R., Jayashree, N., Selvaraj, B., \& Rajendran, A (2010). Assessment of quality of Tinospora cordifolia (willd.) Mier (Menispermacea): Pharacognostical and phytophysicolochemical profile. International Journal of Comprehensive Pharmacy, 5(3), 1-4.

Nawab, A., Yunus, M., Mahdi, A. A., \& Gupta, S. (2011). Evaluation of anticancer properties of medicinal plants from the Indian subcontinent. Molecular and Cellular Pharmacology, 3(1), 21-29. https:// doi.org/10.4255/mcpharmacol.11.04

Nikaido, H. (2003). Molecular basis of bacterial outer membrane permeability revisited. Microbiology and molecular biology reviews, 67(4), 593-656

Njimoh, D. L., Assob, J. C. N., Mokake, S. E., Nyhalah, D. J., Yinda, C. K., \& Sandjon, B. (2015). Antimicrobial activities of a plethora of medicinal plant extracts and hydrolates against human pathogens and their potential to reverse antibiotic resistance. International journal of microbiology, 15. https://doi.org/10.1155/2015/547156

Oguntoye, S. O., Bello, O. M., Emmanuel, O., \& Dada, A. O. (2018) Acetylcholinesterase inhibition and antioxidant evaluation of polyphenolic fractions and oil from four melon seeds used as condiments in Nigeria. Carpathian Journal of Food Science and Technology, 10(1), 82-94.

Pardo-de-Santayana, M., Tardío, J., Blanco, E., Carvalho, A. M., Lastra, J. J. San Miguel, E., \& Morales, R. (2007). Traditional knowledge of wild edible plants used in the northwest of the Iberian Peninsula (Spain and Portugal): a comparative study. Journal of ethnobiology and ethnomedicine, 3(1), 1-11. https://doi.org/10.1186/1746-4269-3-27

Pendry, B., Busia, K., \& Bell, C. M. (2005). Phytochemical evaluation of selected antioxidant-containing medicinal plants for use in the preparation of a herbal formula-a preliminary study. Chemistry $\&$ Biodiversity, 2(7), 917-922. https://doi.org/10.1002/cbdv.200590068

Pisoschi, A. M., Pop, A., Georgescu, C., Turcuş, V., Olah, N. K., \& Mathe, E. (2018). An overview of natural antimicrobials role in food. European Journal of Medicinal Chemistry, 143, 922-935. https://doi. org/10.1016/j.ejmech.2017.11.095

Puupponen-Pimiä, R., Nohynek, L., Alakomi, H. L., \& Oksman-Caldentey, K. M. (2005). Bioactive berry compounds-novel tools against human pathogens. Applied Microbiology and Biotechnology, 67(1), 8-18. https://doi.org/10.1007/s00253-004-1817-x

Qureshi, R. A., \& Chaudhri, M. N. (1988). The Ranunculaceae of Pakistan (Vol. 4). Pakistan Systematics.

Ramchoun, M., Harnafi, H., Alem, C., Benlyas, M., Elrhaffari, L., \& Amrani, S. (2009). Study on antioxidant and hypolipidemic effects of polyphenol-rich extracts from Thymus vulgaris and Lavendula 
multifida. Pharmacognosy Research, 1(3), 106-112.

Rana, M. S., \& Samant, S. S. (2010). Threat categorisation and conservation prioritisation of floristic diversity in the Indian Himalayan region: a state of art approach from Manali Wildlife Sanctuary. Journal for Nature Conservation, 18(3), 159-168. https://doi.org/10.1016/j. jnc.2009.08.004

Rathinam, V. A., \& Fitzgerald, K. A. (2016). Inflammasome complexes: emerging mechanisms and effector functions. Cell, 165(4), 792-800.

Sakai, S., Ochiai, H., Nakajima, K., \& Terasawa, K. (1997). Inhibitory effect of ferulic acid on macrophage inflammatory protein-2 production in a murine macrophage cell line, RAW264. 7. Cytokine, 9(4), 242-248. https://doi.org/10.1006/cyto.1996.0160

Saleem, M., Nazir, M., Ali, M. S., Hussain, H., Lee, Y. S., Riaz, N., \& Jabbar, A. (2010). Antimicrobial natural products: an update on future antibiotic drug candidates. Natural Product Reports, 27(2), 238-254.

Scalbert, A., Manach, C., Morand, C., Rémésy, C., \& Jiménez, L. (2005). Dietary polyphenols and the prevention of diseases. Critical Reviews in Food Science and Nutrition, 45(4), 287-306. https://doi. org/10.1080/1040869059096

Schluger, N. W., \& Rom, W. N. (1998). The host immune response to tuberculosis. American Journal of Respiratory and Critical Care Medicine, 157(3), 679-691. https://doi.org/10.1164/ ajrccm.157.3.9708002

Sen, A., \& Batra, A. (2012). Evaluation of antimicrobial activity of different solvent extracts of medicinal plant: Melia azedarach L. International Journal of Current Pharmaceutical Research, 4(2), 67-73.

Sen, S., Chakraborty, R., Sridhar, C., Reddy, Y. S. R., \& De, B. (2010). Free radicals, antioxidants, diseases and phytomedicines: current status and future prospect. International Journal of Pharmaceutical Sciences Review and Research, 3(1), 91-100.

Shah, N. C. (2005). Conservation aspects of Aconitum species in the Himalayas with special reference to Uttaranchal (India). Medicinal Plant Conservation, 11, 9-15.

Silva, T., Oliveira, C., \& Borges, F. (2014). Caffeic acid derivatives, analogs and applications: A patent review (2009-2013). Expert Opinion on Therapeutic Patents, 24(11), 1257-1270. https://doi.org/10.1517/135 43776.2014.959492

Simpson, J. L., Phipps, S., Baines, K. J., Oreo, K. M., Gunawardhana, L., \& Gibson, P. G. (2014). Elevated expression of the NLRP3 inflammasome in neutrophilic asthma. European Respiratory Journal, 43(4), 10671076. https://doi.org/10.1183/09031936.00105013

Soobrattee, M. A., Neergheen, V. S., Luximon-Ramma, A., Aruoma, O. I., \& Bahorun, T. (2005). Phenolics as potential antioxidant therapeutic agents: mechanism and actions. Mutation Research/Fundamental and Molecular Mechanisms of mutagenesis, 579(1-2), 200-213. https://doi.org/10.1016/j.mrfmmm.2005.03.023

Tak, P. P., \& Firestein, G. S. (2001). NF-kB: a key role in inflammatory diseases. The Journal of Clinical Investigation, 107(1), 7-11.

Tantray, M. A., Tariq, K. A., Mir, M. M., Bhat, M. A., \& Shawl, A. S. (2009). Ethnomedicinal survey of shopian, Kashmir (J\&K), India. Asian Traditional Medicine, 4(1), 1-6.

Tariq, H., Arshad, M., Khan, S., Sattar, H., \& Qureshi, M. S. (2011). In vitro screening of methanol plant extracts for their antibacterial activity. Pakistan Journal of Botany, 43(1), 531-538. https://doi. org/10.1142/9789814354868_0024

Uniyal, A., Uniyal, S. K., \& Rawat, G. S. (2011). Commercial extraction of Picrorhiza kurrooa Royle ex Benth. in the Western Himalaya. Mountain Research and Development, 31(3), 201-208. https://doi.org/10.1659/ mrd-journal-d-10-00125.1.

Utelli, A. B., Roy, B. A., \& Baltisberger, M. (2000). Molecular and morphological analyses of European Aconitum species (Ranunculaceae). Plant Systematics and Evolution, 224(3), 195-212. https://doi.org/10.1007/ BF00986343

Vitalini, S., Iriti, M., Puricelli, C., Ciuchi, D., Segale, A., \& Fico, G. (2013). Traditional knowledge on medicinal and food plants used in Val San Giacomo (Sondrio, Italy)—An alpine ethnobotanical study. Journal of Ethnopharmacology, 145(2), 517-529. https://doi.org/10.1016/j. jep.2012.11.024

Wada, K., Ohkoshi, E., Zhao, Y., Goto, M., Morris-Natschke, S. L., \& Lee, K. H. (2015). Evaluation of Aconitum diterpenoid alkaloids as antiproliferative agents. Bioorganic \& medicinal chemistry letters, 25(7), 1525-1531. https://doi.org/10.1016/j. bmcl.2015.02.018

Watkins, F., Pendry, B., Sanchez-Medina, A., \& Corcoran, O. (2012). Antimicrobial assays of three native British plants used in AngloSaxon medicine for wound healing formulations in 10th century England. Journal of Ethnopharmacology, 144(2), 408-415. https:// doi.org/10.1016/j.jep.2012.09.031

Wild, R. G., \& Mutebi, J. (1996). Conservation through community use of plant resources. People and Plants working paper, 5. Paris: UNESCO.

Yang, C. L., Or, T. C., Ho, M. H., \& Lau, A. S. (2013). Scientific basis of botanical medicine as alternative remedies for rheumatoid arthritis. Clinical Reviews in Allergy \& Immunology, 44(3), 284-300. https://doi.org/10.1007/s12016-012-8329-8

Yang, J., Zhao, F., \& Nie, J. (2017). Anti-rheumatic effects of Aconitum leucostomum Worosch. on human fibroblast-like synoviocyte rheumatoid arthritis cells. Experimental and therapeutic medicine, 14(1), 453-460. https://doi.org/10.3892/etm.2017.4503 